\title{
USING CLUSTERING TECHNIQUE TOWARDS STUDENTS' WRITING SKILL IN RECOUNT TEXT
}

\author{
Nurmala Hendrawaty and Nurfitria Ambarwati \\ Program Studi Pendidikan Bahasa Inggris \\ Fakultas Bahasa dan Seni Universitas Indraprasta PGRI \\ Jl. Nangka 58 Tanjung Barat, Jakarta Selatan \\ malarumapea@gmail.com
}

\begin{abstract}
Clustering is a technique to turn a broad subject into a limited and more manageable topic for short essay or text. It is a technique that can be used to generate ideas in writing. It is also known as diagramming, webbing, looping or mapping. Therefore, the research aims at finding out empirical evidence concerning whether clustering technique is effective or not for students to write a recount text. The method used in this research was quantitative, and the research design was a quasi-experiment. The sample of this research was the tenth grade students of SMK Mahadika 1 Ciracas Jakarta. The experimental class is from X AP 1, and the control class is from and X AP 3 with 30 students from each class. Based on data analysis, the range score from experimental class is 57-86, while from control class is 50-84. Furthermore, the research findings shows that $t_{\text {count }}=3.098$ and $t_{\text {table }}=2,002$ with the significance degree of $\alpha=0,05\left(t_{\text {count }}>t_{\text {table }}\right)$. Since $t_{\text {count }}$ is higher than $t_{\text {table, }}$, it means that $H_{1}$ is accepted. It can be concluded that there is a significant effect of using clustering technique towards students' writing skill in recount text.
\end{abstract}

Keywords: Clustering Technique, Writing Skill, Recount Text

\begin{abstract}
Abstrak
Clustering adalah teknik untuk mengubah topik yang luas menjadi topik yang terbatas dan mudah diatur untuk esai atau teks singkat. Teknik ini bisa digunakan untuk menghasilkan ide dalam menulis. Teknik ini juga dikenal sebagai diagram, anyaman, perulangan atau pemetaan. Oleh karena itu, penelitian ini bertujuan untuk mengetahui bukti empiris mengenai apakah teknik clustering efektif atau tidak bagi siswa untuk menulis teks recount. Metode yang digunakan dalam penelitian ini adalah kuantitatif, dan rancangan penelitiannya adalah percobaan kuasi. Sampel penelitian ini adalah siswa kelas XI SMK Mahadika 1 Ciracas Jakarta. Kelas eksperimen berasal dari X AP 1, dan kelas kontrol berasal dari dan X AP 3 dengan 30 siswa dari masing-masing kelas. Berdasarkan analisis data, range skor dari kelas eksperimen adalah 57-86, sedangkan dari kelas kontrol adalah 50-84. Selanjutnya, hasil penelitian menunjukkan bahwa $t_{\text {hitung }}=3,098$ dan $t_{\text {tabel }}=2,002$ dengan tingkat signifikansi $\alpha=0,05\left(t_{\text {hitung }}>t_{\text {tabel }}\right)$. Karena jumlah $t_{\text {hitung }}$ lebih tinggi dari $\mathrm{t}_{\text {tabel}}$, berarti $\mathrm{H}_{1}$ diterima. Dapat disimpulkan bahwa ada pengaruh yang signifikan dari teknik clustering terhadap kemampuan menulis siswa dalam teks recount.
\end{abstract}

Kata Kunci: Teknik Pengelompokan (Clustering), Keterampilan Menulis, Teks Recoun

\section{INTRODUCTION}

English is one of the international languages used for communication all over the world. In Indonesia, English has become the first foreign language which is taught from elementary up to university. Besides, English is a subject to pass the national examination. In learning English, a learner is excepted to master the four basic language skills (listening, speaking, reading, and writing). The language skills are divided into two, which are receptive 
skills and productive skills. The receptive skills are listening and reading, whereas the productive skills are speaking and writing.

Writing is a process of transforming thoughts, ideas, and feelings into written form. It means that writing is one of the important skills that must be learned by students. Dealing with the purpose of writing, in general writing is to communicate and give information to others indirectly, to explain about who or what something is and how it happened or why something happened, to persuade the reader to take action based on what the author has written, to express thought, idea, and feeling of author on a specific topic. The purposes of writing for students are to express their ideas on a specific topic, explore their vocabulary knowledge, and write a composition properly.

Writing is indirect communication that conveys meaningful and expressive information from the author to the readers in form of written language. Writing is also a good way to develop students' English ability. By writing students are able to learn some components of writing such as capitalization, punctuation, spelling, vocabulary, and grammar. The process of writing will be successful if students' writing contains the components of writing, and it is done correctly.

There are some types of English text that have to be mastered by the vocational high school students; three of them are recount, procedure, and descriptive. Each of text type has different purposes, organizational structure of the text and language features that can be used in a text. One of the texts learned by students when the researcher conducted a research was a recount text.
Recount text is a text that retells past events an experience in chronological order. It purposes to provide the reader with a description of what occurred and when it occurred. The generic structure of recount text consists of orientation, event, and reorientation. In orientation, it provides background information of the event. In event, it gives more information about what happened in sequence. Then in reorientation will describe the conclusion of the story and what the writer felt when it happened. In learning writing, the students face many problems in writing recount text when they are ordered to write a text. First is vocabulary. The students are poor at vocabulary for constructing a good paragraph; as a result, they cannot convey their ideas and opinions smoothly. Second is grammar. A good text describes a sentence structure correctly, and the paragraph has a good order of the words in sentence sequence. Third is content. It means that the students cannot produce an effective text because they cannot construct the main idea and supporting details. Fourth is organizing. In organizing, the students cannot organize their writing into a good text.

These problems are influenced by some factors. Based on the researcher's experience while conducting Program Pengalaman Lapangan (PPL) at SMK Mahadika 1 Ciracas Jakarta, the problems come from the teaching technique in learning writing. The teacher gets used to teaching with a conventional technique. The teacher just gives some explanations and exercises from the textbook. It makes students less comprehensible the material, and the students cannot produce their own sentences in English. Some students think that the class will be boring when they learn English subject. 
To solve these problems, a teacher of English subject needs another innovative and interesting technique in teaching writing. In addition, the technique meets students' need and interest. In the process of teaching and learning, there are a lot of techniques that can be applied in learning writing. One of them is clustering technique.

Clustering is a technique to turn a broad subject into a limited and more manageable topic for short essay or text. Clustering technique is also known as diagramming or mapping. It is a technique that can be used to generate ideas in writing. This technique is helpful to think in a visual way. In clustering technique, there are lines, boxes, arrows, and circles to show relationship among the ideas and details. In clustering technique, the students write a topic in the center of a piece of paper, then write ideas suggested by the topic around it, connect these to the topic with lines, and follow the same procedures with their subtopics. The advantages of this technique are students are able to find out the related words, ideas, concepts as many as possible to the topic given, can stimulate their ideas and organize their idea before they develop into paragraphs.

On the basis of the background, this research aims at finding out the effect of using clustering technique towards students' recount text. As a result, the research title is the effect of using clustering technique towards students' writing skill in recount text at the tenth grade students of SMK Mahadika 1 Ciracas Jakarta.

\section{The Nature of Writing}

Writing is a process of transforming thoughts, ideas, and feelings into written form. Hyland (2003: 9) supported that writing is way of sharing of personal meanings and emphasizes the power of the individual to construct their own views on a topic. It means that writing is one of the important skills that must be learned. Writing will make students learn any aspects of language such as grammatical aspect and language used. In shorts, writing is a good way to develop students' English ability.

Writing is how a produce a written product. The process involves a series of thinking activities in which the writers have to transform their ideas coherently and cohesively into written text. According to Brown (2001: 337), writing is transaction with words whereby you free from what you presently think, feel, and perceive.

In addition, Harmer (2004: 86) stated that writing is a process that what we write if often heavily influenced by the constraints of genres. Then these elements have to be present in learning activities. It means that writing cannot be separated with genres especially in teaching learning activities of writing. In this case, writing activities can be present in a classroom

From all the statements above, it can be concluded that writing is an activity of thinking after which it is express into graphic symbols, in a communicative written language. In expressing the thought into a written language, feeling plays an important role as well. Therefore, product will be easily understood and enjoyed by the readers. To do so, of course, it needs a good and interesting language. In other words, writing is closely related with the thought, feeling, and ability in using a language. In this case, a communicative is completely needed.

\section{Writing Recount Text}

There are some genres of the English texts that should be studied by 
vocational high school students; one of them is recount text. Priyana et al (2008: 69) stated that a recount text is document series of events and evaluate their significance in some way. It focuses on sequence of events, all which relate to the occasion. It means in details, that recount involves what happened, who was involved, when the events that happened, where the events took place and how the events could have happened. As mention above, recount is use to retell about an event that has occurred in the past. Therefore, recount is always written in the past tense. It is important that the writer have to aware about it. Further, when writing recount also should concern on the sequence of the events that can more developed.

Knap and Walkins (2005: 224) said that recount structure and grammar is similar with narrative genres that retells past events, usually in order to in which they happened. It means that a recount text tells about something that has happened in the past chronologically. In addition, Hyland (2009: 3) said that in recount text, the writer may write all past events not only retell about factual or historical events but based on their personal experience. It means that writing about past event, personal experience, factual or historical events, that has happened is called by recount text. The students must have their own past stories about their lives such as, their holiday, terrible moment and happy moment.

From some definitions above, it can be concluded that recount text is a kind of text type which retell about past events chronologically. Those part past events can be about factual events or historical events and the students' personal experience that is usually learned in vocational high school in Indonesia. Recount text uses past tense to retell the events. Therefore, the students need pay attention to grammar, e.g. mastering the forms of regular and irregular verbs and language for not making misunderstanding and miscommunication to the readers.

\section{The Purpose of Recount Text}

According to Hyland (2003: 20), the purpose of recount is to reconstruct experiences by retelling in original sequences. The other purpose of recount text is to tell or amuse the reader or audience. It is in line with Wardiman, et al. (2008:124) that the social function of recount text is to give readers a description of what occurred and when it that purpose of informing and entertaining. From its purpose, recount is not only to retell the past activities that happened, but to inform the reader about some information that happened. For example, retell the facts about disaster that happened like in the newspaper or magazine.

Widiyati (2008: 124) also supported that the social function of recount text retells events for the purpose of informing and entertaining. It means recount is a way of retelling an important events or describing an experience that we had to others for some reasons or purpose. Therefore recount can really help to imagine what an experience was like.

\section{The Generic Structure of Recount Text}

In writing, the students do not only pour their idea they want, but they have to think about the content of their writing. The content should be clear written in order to make the reader easy to understand about the plot of story and information that students wanted to give. To make the writing easy to understand for the readers, there must be stricter of the writing. 
In writing a good recount text, there are some generic structures that the students should know in order to make the text coherence to each paragraph. According to Stubbs (2000: 8 ), the generic structure of recount text consists of three parts, namely orientation, events and reorientation. The further explanation about generic structure in recount text is depicted below.

1. Orientation

In orientation, it provides the setting and introduces the participants about the text. It told the reader who was involved, what happened, where this event took place, and when it happened. For example, an orientation for a recount text of a climb of Mount Everest, the students should tell the reasons for the climb and an explanation of the climb conditions.

2. Events

This part tells what happened in sequence. It gives more information about the story and gives the details of what, who, where, and when. The events can be told in chronological order (the order in which they happen) use conjunction or connectives like: first, next, then, finally, and so on. This part also tells how the characters of the story react to the complication.

3. Reorientation

Reorientation is a conclusion of the events or the end of the story. It is offers personal opinion or comment of the recount text. Reorientation generally refers to some of the information in the orientation paragraph.

The following text is the example of generic structure recount text.
My Holiday

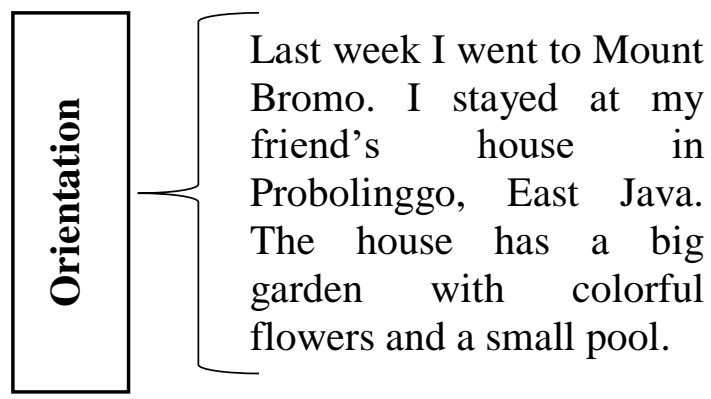

In the morning, my friend and I saw Mount Batok. The scenery was very beautiful. We rode on horseback carefully. It was scary, but it was fun. Then we went to get closer look at the mountain. We took pictures of beautiful scenery there. After that, we took a rest and had lunch under a big tree. Before we got home, we went to the zoo at Wonokromo. We went home in the afternoon.

went to the zoo at
Wonokromo. We went
home in the afternoon.
We were very tired.
However, I think it was
really fun to have a
holiday like this. I think it
was really fun to have a
holiday like this. I hope
my next holiday will be
more interesting.

\section{The Language Features of Recount} Text

Besides the generic structures of recount text, the writer also should know about the language features that used in recount text. Language feature of the text is the essential part in writing a text. It also can be used to identify what kind of the text is. Anderson (2005: 50) defined them as follows: 
1. Proper Noun

Proper noun in recount text is used to identify who are those involved in the text.

2. Descriptive Words

Those words are used to give details about what, when, where, and how. Descriptive words are usually adjective that used to describe the noun or personal attitude, like happy, wonderful curious, fun, etc.

3. The Use of Past Tense

Recount test is a text that retell someone experience and of course it used in simple past tense, past continuous tense, past perfect tense and past perfect continuous tense.

4. Sequence Maker

Sequence maker means words that show the order of events (for example next, first, then).

\section{Clustering Technique}

According to Richards and Rodgers (2001: 19), technique is the implementation that takes place in a classroom. It's like a particular tricks, stratagem, or contrivance used to accomplish an immediate objective. Technique must be consistent with a method, and therefore in harmony with an approach well.

Sometimes when people are going to write they feel hard to find out what they know about the topic or develop the ideas they have. Therefore, people have to know about how to write well to get a good composition in their writing. Writing well comes from working through a process of writing. In the writing process there are some steps that will guide us to produce good writing. One of the steps is prewriting process. This step is the first step in writing process. This step is also the important step to organize the ideas before the writer start to write. There are many techniques that can be used in this step. One of the techniques is clustering technique.

According to Langan (2005: 27), clustering is also known as diagramming or mapping which is another strategy that can be used to generate material for a paragraph. This method is helpful for people to think in a visual way. It means we can use lines, boxes, arrows and circle in implementing the clustering to show the idea and details that are exist in our mind.

Lunsford (2010: 57) said that clustering is a prewriting technique used by writers to produce ideas using a visual scheme or chart. It means that clustering is a creativity activity. When creating a clustering, a writer tries to find things related to the topic using a visual scheme or chart. It is might be helpful for the writer to understand the relationships among the parts of broad topic and to develop subtopics.

In addition, Meyers (2010: 57) stated that clustering is another effective method that we could use to narrow a subject. To cluster, write the subject in the middle of the page and then circle it and write related ideas around circle around the subject. Through clustering technique, a writer will be easy to give an idea of what will be written especially helpful visual learners. In a cluster diagram the central events or components of an essay are presented visually, more detailed events branch of the main events to provide a visual overview of the entire ideas. Clustering is a good way to turn a broad subject into a limited and more manageable topic for a short essay; it also called mapping, webbing, looping, or diagramming.

From the definitions above, it can be summarized that clustering is making 
a visual map or new association that allows thinking more creatively and to begin without clear ideas. Clustering will help the students how to associate the ideas, how to write down the ideas that exist in their minds, and how to develop ideas into a good paragraph unity. Clustering can be useful for any kind of writing. Besides, clustering does not only write all ideas that is exist, but we also can omit the ideas that has been written if it is far from the topic in the center. Writers use it in the early stages of planning an essay in order to find subtopic in a topic organize information. Writers can use clustering to plan brief section of an essay as they are drafting.

\section{Steps of Using Clustering Technique}

According to Clouse (2005: 2426) said that clustering is a way of generating and connecting ideas visually". It is useful for seeing how various ideas relate to one for developing subtopics. Writers use it in the early stages of planning essay in order to find subtopics in a topic or to organize information. Here are the steps of clustering.

1. Take a sheet of paper and write your main topic in the middle of a sheet of paper and circle it.

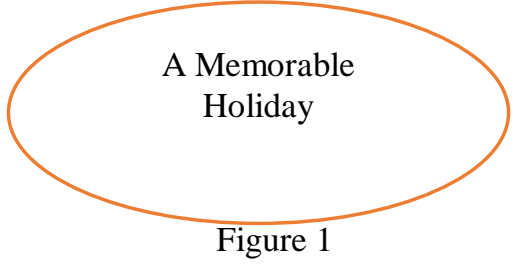

The Circle of Main Topic (beginning stage)

2. Write ideas relating to the topic around it, circle them, and connect them to the central circle. Write them quickly, move into another space, write some more down, move to another blank, and just keep moving around and writing.

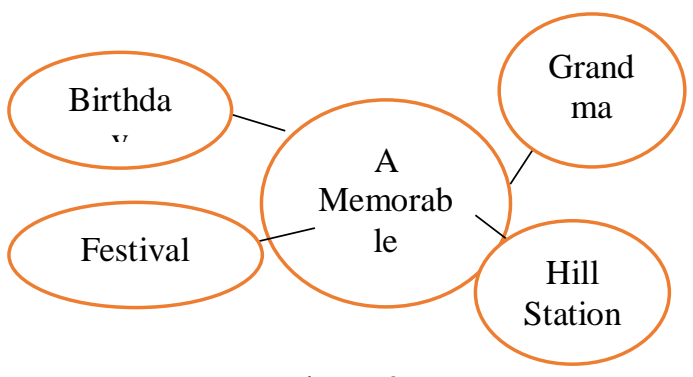

Figure 2

Grouping Ideas (second stage)

3. Write down ideas, examples, facts, or other details relating to each idea and join to the appropriate circles.

4. Repeat. As you write and circle new words and phrases, draw lines back to the last word, the central word, or other words that seem connected.

5. Keep going until we can think nothing else relating to our topic. Then see a set of cluster that have done, if one particular circle of the clustering is enough to begin a draft, we can cluster again to expand the branches and we also can cross out the words and phrase that seem irrelevant, and begin to impose some order by clustering and begin to a first draft in writing.

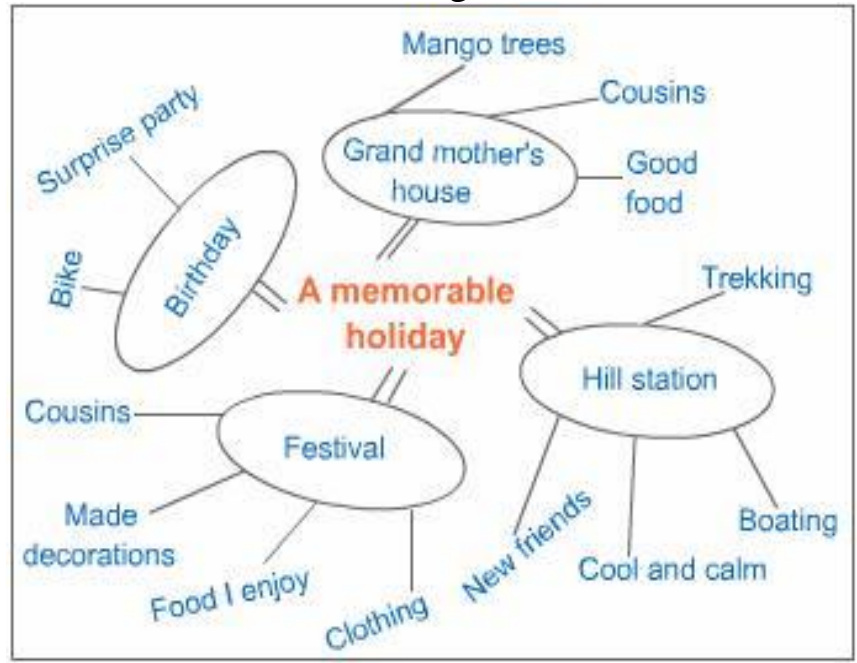

Figure 3

Finishing of Clustering (last stage)

\section{Teaching Procedures}

The procedures of teaching recount text through clustering technique is applied in the teaching and 
learning process aimed to help students how to associate the ideas, how to write down the ideas that exist in their minds, and how to develop ideas into a good paragraph unity.

Here the following steps in teaching writing recount text using clustering technique:

1. Pre Writing

Introduce the concept of clustering technique to the students.

Then tell students clustering technique would help in generate ideas when they started to write.

Teacher gives the students topic discuss and leading them to generate ideas in form clustering technique on the whiteboard as a model. Put the topic in the centre and circle it or use other shapes to make it more interesting, and put keywords related to the topic by using lines or arrows. Students do not worry in generating ideas. It is free for them to organize their ideas as long as related to the topic given.

\section{Whilst Writing}

Teacher explains about recount text, including the kinds of recount, generic structure of recount text, and language features.

Ask the students to write the first draft based on the design of clustering technique samples that have been showed on the whiteboard Next, teacher also guides students when they start writing their first draft on their writing.

After students are able to use clustering technique, ask them to make their own clustering and leads the students while they work to make clustering of the topic to make a personal recount text referred to their own experience.
3. Post Writing

Giving students an evaluation to check their ability in writing recount text and to know their problems in writing.

\section{METHODOLOGY}

The research was conducted at SMK Mahadika 1 Ciracas Jakarta, and it took from 28 April to 5 May, 2017. The method used in this research was quantitative method. Quantitative research explains how one variable affects another. The design of this research is experimental design. This design looks and studies the effects after the subject is given independent variable treatment. The population of this research was all the tenth grade students of SMK Mahadika 1 Ciracas Jakarta with the total number was about 180 students. 60 students were taken from two classes for the sample. Purposive sampling was used to select a sample that represented the population or included subjects with needed characteristics. To collect the data, a written test was used as instrument. To assess the tenth grade students' writing recount text, the researcher used the analytical recount writing content rubric consisting of content, organization, vocabulary, language use, mechanic. Lilliefors and Fisher formulas were used to find out normality and homogeneity tests. Finally, $t_{\text {test }}$ in the hypothesis was used to calculate the data to see different significance results both experimental and control classes.

\section{RESULT AND DISCUSSION}

This research was conducted by comparing the results of students' writing recount score of experimental class, which was taught using clustering technique, and the results of students' 
writing recount score of control class which was taught conventional method or without using clustering technique. The test was given to students that became the samples of the research. The sample in this study used purposive sampling. Based on data analysis and calculation data, the result of the research of the experimental class had range of score 57-86, mean 72.17, median 72.2, modus 72.75, standard deviation 63, variance 7.93. Moreover, the experimental class was derived from the normal distribution and homogeneous. $\mathrm{L}_{\text {count }}$ was 0.0859 and $\mathrm{L}_{\text {table }}$ was 0.161 with $\alpha=0.05$ and $n=30$. On the other side, the result of the research in the control class had range of score 50-84, mean 66.5, median 65.7, modus 62.7, standard deviation 49,86, and variance 7.07. Moreover, the control class was derived from the normal distribution and homogeneous. $\mathrm{L}_{\text {count }}$ was 0.1368 and $\mathrm{L}_{\text {table }}$ was 0.161 with $\alpha=0.05$ and $n=30 . F_{\text {count }}$ was 1,26 and $F_{\text {table }} 1,85$. From the hypothesis test, it was found $t_{\text {count }}=3.098$ and $t_{\text {table }}=$ 2.002. It shows that $t_{\text {count }}$ is higher than $\mathrm{t}_{\text {table which }} \mathrm{H}_{0}$ is rejected and $\mathrm{H}_{1}$ is accepted.

Based on the research findings, it can be interpreted that using clustering in writing a recount text will enhance the students' skill in writing recount text. It proves that clustering technique can help the student to organize their ideas much more than without using clustering technique. In addition, it can develop students' writing skill at SMK Mahadika 1 Ciracas Jakarta.

\section{CONCLUSIONS}

The purpose of this research is to find out whether or not there is an improvement in learning recount text through clustering technique towards students' writing skill in recount text.
Based on the research carried out at the tenth grade of SMK Mahadika 1 Ciracas Jakarta academic year 2016/2017, it can be concluded as follows:

In experimental class highest score of writing recount text of is 86 and the lowest score is 56 and in control class the highest score of writing recount text is 86 and the lowest score is 56. Based on the result of data analysis that mean score in experimental class is 72.17 , whereas in the control class is 66.5. Furthermore, $t_{\text {count }}=3.098$ and $t_{\text {table }}=2,002$, so $t_{\text {count }}>$

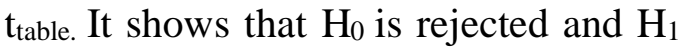
is accepted. It means that there is the effect of using clustering technique towards students' writing skill in recount text.

\section{REFERENCES}

Anderson, M and Kathy, A. (2005). Text Types in English. South Yarra: Macmillan.

Brown, H. D. (2001). Language Assessment:Principles and Classroom Practices. New York: Longman Pearson Education.

Clouse, B. F. (2005). A Troubleshooting Guide Strategies and Process Writers. New York: McGrawHill.

Harmer, J. (2004). How to Teach English. New York: Longman Pearson Education.

Hayland, K. (2003). Second Language Writing. New Yor: Cambridge University Press.

Knap, P and Walkins. (2005). Genre, Text, Grammar Technologies for Teaching and Assessing Writing. Sydney: University of South Wales. 
Longman, J. (2005). English Skills with Reading. Seventh Edition. New York: Pearson Education.

Lunsford, A. A. (2010). The St. Martin's Handbook. Bedford: St. Martin's.

Meyers, A. (2005). Gateway to Academic Writing. New York: Pearson Education.

Priyana, J et al. (2008). Scaffolding English for Junior High School Students Grade VIII. Jakarta. Pusat Perbukuan Nasional.

Richards, J and Rodgers. (2001). Approaches and Methods in Language Teaching. New York: Cambridge University Press.

Wardiman, A. et al. (2008). English in Focus for Grade VIII Junior High School (SMP/MTs). Jakarta: Pusat Perbukuan Departemen Pendidikan Nasional.

Widiyati, U. et al. (2008). Contextual and Teaching Learning Bahasa
Inggris Kelas VIII. Jakarta: Pusat Perbukuan Nasional.

Internet:

Basic Writing for ESL Students. Retrieved March 10, 2017 from http://qkfcfaxzczyj.ddns.net/diff erent-writing-techniques379685.html.

Ddns. Retrieved March 10, 2017 from http://web2.uvcs.uvic.ca/elc/sam ple/beginner/wt/wt_04.html.

Smartstat. Retrieved May 14, 2017 from http://www.smartstat.info/downl oad/tabel-distribusi/tabel-nilaikritis-lilliefors-untuk-ujinormalitas.html?view=summary

Smartstat. Retrieved May 14, 2017 from http://www.smartstat.info/downl oad/tabel-distribusi/tabel-nilaikritis-lilliefors-untuk-uji$\underline{\text { normalitas.html }}$

Unikom. Retrieved May 14, 2017 from http://repository.unikom.ac.id/49 416/1/distribusi-fisher-f.pd 